\title{
OS ESTUDOS CULTURAIS E A ANÁLISE CULTURAL DA TELEVISÃO: CONSIDERAÇÕES TEÓRICO-METODOLÓGICAS ${ }^{1}$
}

\author{
THE CULTURAL STUDIES AND THE CULTURAL ANALYSIS OF TELEVISION: \\ THEORETICAL AND METHODOLOGICAL CONSIDERATIONS \\ ESTUDIOS CULTURALES Y EL ANÁLISIS CULTURAL DE LA TELEVISIÓN: \\ CONSIDERACIONES TEÓRICAS Y METODOLÓGICAS
}

\author{
Simone Maria Rocha \\ Doutora em Comunicação e Cultura/UFRJ \\ Professora do PPGCOM/UFMG \\ smarocha@ig.com.br
}

\begin{abstract}
Resumo
O propósito deste artigo é apresentar uma revisão teórico-metodológica sobre estudos de televisão na perspectiva dos estudos culturais: um projeto teórico-político inspirado nas ciências humanas que, ao entrelaçar as fronteiras da análise textual da cultura popular com a teoria social, conferiu papel central à dimensão da cultura. Nosso percurso contempla os desdobramentos da análise cultural da televisão relativos à polissemia do texto televisivo, à noção de fluxo (Williams, 1974) e à perspectiva da audiência e finaliza com uma proposta metodológica que retoma a noção de modos de endereçamento. Acreditarmos que tal proposta permite-nos investigar tanto aquilo que é característico da linguagem televisiva quanto lidar com especificidades do contexto sócio-cultural no qual o produto está inserido.
\end{abstract}

Palavras-chave: Análise Cultural. Estudos Culturais. Televisão.

\begin{abstract}
The purpose of this paper is to present a theoretical and methodological review about the studies of television from cultural studies perspective. Cultural studies is a theoretical and politics project in Humans sciences that, by intertwining the boundaries of the textual analysis of popular culture with social theory, conferred the central role of culture dimension. Our course covers the developments of the cultural analysis of television concerning the polysemy of the text of television, the concept of flow (Williams, 1974) and the viewer's perspective. We will conclude with a methodology that takes the concept of modes of address. We believe that this proposal allow us to show what is characteristic of television language and also to deal with the specificities of social and cultural context of which the product makes part.
\end{abstract}

Keywords: Cultural Analysis. Cultural Studies. Television.

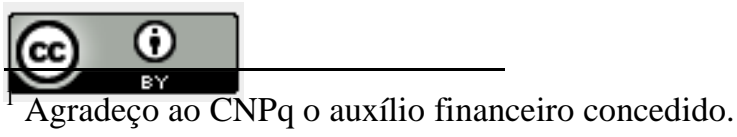

ANIMUS Rev. Interamericana de Comunicação Midiática, Santa Maria, v.10, n.19, sem. 2011, E-ISSN 2175-4977 


\section{Resumen}

Esta obra está licenciada sob uma Licença Creative Commons

El propósito de este artículo es revisar los estudios teóricos y metodológicos de la televisión desde la perspectiva de los estudios culturales: un proyecto teórico y político inspirado en las humanidades que, por el entrelazamiento de las fronteras del análisis textual de la cultura popular con la teoría social, dado el papel central de la dimensión de la cultura. Nuestro curso cubre los acontecimientos de los análisis cultural de la televisión en la polisemia del texto de la televisión, el concepto de flujo (Williams, 1974) y la perspectiva de la teleaudiencia y concluye con una propuesta metodológica que toma el concepto de modos de direccionamiento. Creemos que esta propuesta nos permite investigar tanto lo que es distintivo de la televisión cómo hacer frente a las especificidades del contexto sociocultural en el que se inserta el producto.

Palabras clave: Análisis Cultural. Estúdios Culturales. Televisión.

\section{INTRODUÇÃO}

A literatura sobre televisão oscilou numa disputa entre aqueles que consideravam que as instituições de transmissão determinavam o significado social e aqueles que pensavam que os telespectadores interpretavam livremente o que eles assistiam. As diversas posições teóricas ocasionaram metodologias de pesquisa específicas. Críticos sociais como Neil Postman (1985), seguindo a trilha da Escola de Frankfurt, pensavam a comunicação enquanto uma relação direta entre emissor e receptor. Os pesquisadores dos Usos e Gratificações viam um processo mais refratário, onde as experiências de vida e as necessidades pessoais ajudavam a determinar as interpretações dos telespectadores. A primeira abordagem era um tanto retórica e não foi capaz de oferecer uma confirmação empírica. A última era empiricamente baseada, mas esbarrava na dificuldade de definir e medir as necessidades dos telespectadores. A pesquisa dos Usos e Gratificações também tendeu a emperrar em debates sobre os prejuízos que a televisão impunha. Houve outra importante tradição da pesquisa empírica dentro dos efeitos psicológicos da televisão. Efeitos diretos, entretanto, permaneciam difíceis de provar. De um modo geral esses estudos tendiam a isolar os processos de assistência à TV dos interesses sociais mais amplos. O principal problema dessas pesquisas é que elas eram baseadas no ato de ver televisão em condições controladas em laboratório, um contexto de assistência muito artificial.

Já as abordagens etnográficas da pesquisa em televisão começaram a levar em conta um conjunto de fatores mais complexos incluindo o impacto social geral e os contextos 
específicos de assistência. Este trabalho desafiou as metodologias empíricas positivistas e legitimou a pesquisa qualitativa. E esta foi a trajetória seguida pelos teóricos ligados aos Estudos Culturais.

\section{A TRAJETÓRIA DA ANÁLISE}

Os Estudos Culturais combinaram duas estratégias metodológicas sobrepostas cujo objetivo era entender como a luta cultural opera. Uma dessas estratégias vinha da análise textual semiótica e estruturalista e muito beneficiou a análise qualitativa.

No final dos anos 1960, Roland Barthes revitalizou a linguística estruturalista de Ferdinand Saussure para oferecer um novo quadro de análise dos media. Para os teóricos semioticistas, as mensagens midiáticas são como textos que inscrevem os leitores em posições de sujeitos particulares. Parte desta análise também se constituía por uma crítica às relações capitalistas dominantes ${ }^{2}$. Jacques Lacan retrabalhou a psicanálise de Freud para explicar o modo pelo qual a ordem simbólica da linguagem fabrica a sociedade. É através da linguagem que os indivíduos produzem sentido e articulam suas experiências no mundo. Práticas significativas são, portanto, de cruciais à comunicação.

A análise semiótica foi aplicada ao cinema, mas também se fez útil aos estudos de televisão - considerada como um sistema de códigos e convenções que pode ser estudado como um texto cultural que nos revela as práticas da linguagem. Essas práticas envolvem tanto os profissionais quanto as audiências ${ }^{3}$. Sendo assim, o texto e a estrutura da televisão muito nos revelariam sobre a experiência contemporânea como, por exemplo, a ordem social a qual construímos (Williams, 1989). A partir dessa perspectiva os pesquisadores puderam fazer uso de várias ferramentas analíticas para entender a televisão.

\footnotetext{
${ }^{2}$ Em "Visual pleasure and narrative cinema", publicado em 1975 na revista Britânica Screen, Laura Mulvey se apropriou da teoria psicanalítica para demonstrar o modo pelo qual o inconsciente da sociedade patriarcal estruturou a forma do filme. De acordo com Mulvey a estrutura narrativa e a linguagem cinematográfica acabam incutindo valores sociais dominantes no inconsciente dos espectadores. A subjetividade do espectador é constituída pela sua conformidade com as ideias que eram expressas na tela. O modo como os indivíduos viam e sentiam prazer ao assistir um filme era estruturado desta forma: as únicas posições possíveis para o leitor eram aquelas inscritas pelo texto. O indivíduo era um sujeito descentrado e conduzido pelos media a um processo contínuo de formação identitária. Cf. Mulvey, 1975.

3 Adotamos termos relacionados como espectador(es), audiência(s) e receptor(es) para nos referirmos aos diferentes modos às pessoas que assistem televisão. Estamos cientes das discussões que ocorrem em torno dessas noções, mas tal debate sobre terminologia foge de nosso propósito neste texto. Cf. Fiske, 1987.
}

ANIMUS Rev. Interamericana de Comunicação Midiática, Santa Maria, v.10, n.19, sem. 2011, E-ISSN 2175-4977 
A outra estratégia derivou da etnografia e contribuiu para desvendar os sentidos que os sujeitos produzem das mensagens que recebem, pois, como observou Stuart Hall, quando as próprias práticas de significação começam a ser investigadas o que vemos é uma mudança significativa nas análises dos media. A partir disso, começou-se a entender que a televisão não é um conjunto de conteúdos neutros, uma vez que o próprio meio está ativamente engajado na produção de sentido.

O trabalho de Hall e de seus colegas no Centro de Estudos Culturais Contemporâneos descartou o que ainda havia de hipodérmico no modelo de comunicação. Hall propôs um modelo de comunicação que inclui produção e recepção como diferentes momentos do processo: codificação é a definição do sentido dentro da forma textual, influenciada pelas práticas dos profissionais dos media e decodificação é o trabalho feito pelo receptor para produzir sentido desses textos.

O ensaio codificação/decodificação (2003a) foi visto como o ponto de virada nos Estudos Culturais ao introduzir a ideia de que os programas de televisão são textos relativamente abertos, capazes de serem lidos de diferentes modos por diferentes pessoas. Hall também sugeriu que há uma correlação entre as situações sociais das pessoas e os sentidos que elas podem gerar de um programa. Ele assim postulou uma possível tensão entre a estrutura do texto, que sustenta a ideologia dominante ${ }^{4}$, e as situações sociais da audiência. Ver televisão tornou-se um processo de negociação entre o espectador e o texto.

Hall desenvolveu sua teoria da leitura preferencial para dar conta deste conflito de interesses e identificou três posições hipotéticas: leitura preferencial, negociada e oposicionista. A teoria da leitura preferencial propôs que os programas de TV geralmente optam por um conjunto de sentidos que trabalham para manter a ideologia dominante, mas que esses sentidos não podem ser impostos, apenas preferidos. O leitor cuja posição social se alinha com a ideologia dominante, a tomará como base para reafirmar seu quadro ideológico, através do qual ele vê o mundo e produz sentido tanto de si mesmo quanto de sua experiência social. Ao interpretar uma mensagem ele o fará a partir da posição de sujeito construída para

\footnotetext{
${ }^{4}$ Em entrevista concedida por ocasião dos 25 anos do artigo codificação/decodificação Hall reconheceu que "O modelo descrito no artigo, realmente, faz com que as instituições de comunicação pareçam bastante homogêneas no seu caráter ideológico, mas elas não o são. O modelo não está suficientemente atento para isso. (...) Ele trata a institucionalização da comunicação como algo demasiadamente unidimensional e diretamente relacionado à ideologia dominante". Cf. Hall, 2003b, p. 368.
}

ANIMUS Rev. Interamericana de Comunicação Midiática, Santa Maria, v.10, n.19, sem. 2011, E-ISSN 2175-4977 
ele $^{5}$. Uma leitura negociada é aquela que encaminha a ideologia dominante na direção da experiência social de uma visão particular de um grupo. As leituras são oposicionais quando vão contra o texto para desconstruir a ideologia dominante.

A leitura característica da televisão provavelmente é a negociada. Está é uma concepção de base dos estudos culturais. Se nossa sociedade é vista como uma estrutura de diferentes grupos de interesses, e se a televisão apela a uma ampla audiência, esta deve ser vista como uma mistura daqueles grupos, cada um em uma relação diferente com a ideologia dominante. Os Estudos Culturais vem a experiência televisiva como um movimento dinâmico constante entre similaridade e diferença. A dimensão da similaridade é aquela conformada pela ideologia dominante e está estruturada na forma em que um programa é comum a todos os espectadores para quem ele é popular. A dimensão da diferença, contudo, dá conta da ampla variedade de grupos a quem este programa, em virtude de sua popularidade, deve alcançar. O jogo entre similaridade e diferença é um modo de experimentar a luta entre hegemonia e resistência ${ }^{6}$.

\section{A ANÁliSE CULTURAL E SEUS DESDOBRAMENTOS}

Os Estudos Culturais muito investem na pesquisa acerca da produção de sentidos realizada pelos sujeitos quando do uso dos produtos televisivos. A pesquisa de audiência concentra-se nos modos pelos quais espectadores reais negociam sentidos textuais. Nomes importantes, como os de John Fiske e de John Hartley (1978), seguiram propondo o poder do espectador ativo sem deixar de lado a investigação que se dedica a decifrar os códigos e convenções das mensagens televisivas.

\footnotetext{
${ }^{5}$ Assim a abordagem de Althusser acerca do poder da ideologia dominante, ao atuar através da linguagem e dos textos para construir o leitor como um sujeito na ideologia, pode dar conta apenas da 'leitura preferencial' de Hall. A noção de hegemonia de Gramsci, com sua ênfase na luta constante da ideologia dominante para vencer o consenso do subordinado e incorporar ou neutralizar as forças opositoras, sustenta as duas outras estratégias de leituras - aquelas que produzem leituras negociadas ou oposicionais.

${ }^{6}$ Entre os esforços teóricos de S. Hall está aquele de pensar a mediação entre os paradigmas que sustentaram essas estratégias metodológicas - o culturalismo e o estruturalismo. Os trabalhos realizados na década de 70 acabaram por revelar uma tensão entre o entendimento de cultura ligado à experiência e a abordagem estruturalista e sua centralidade nas estruturas de significação. "Em outros termos, transparece um confronto entre a ação do sujeito e a determinação do sujeito pela linguagem" (Escosteguy, 2001, p. 75). Ao mesmo tempo em que Hall apresenta críticas a ambos os paradigmas, tornando-os secundários, mas não excluídos da análise, ele se aproxima da noção de hegemonia particularmente do modo desenvolvido por Antônio Gramsci. Cf. Hall, $2003 \mathrm{c}$.
} 
Fiske em Televison culture (1987) esclareceu tanto o que considera como televisão bem como o que entende por cultura. A televisão ele definiu como um apoiador/provocador de sentidos e prazeres variados cuja geração e circulação dentro da sociedade ficariam a cargo da cultura. Televisão como cultura é uma parte crucial da dinâmica social pela qual a sociedade se estrutura e se mantém num processo constante de produção e reprodução. $\mathrm{O}$ autor focou sua abordagem no modo como a textualidade da televisão torna-se significativa e prazerosa para seus espectadores, situados em vários contextos, sem deixar de levar em conta sua dimensão e status como uma mercadoria na economia capitalista.

A preocupação dos autores ligados aos Estudos Culturais esteve voltada para a problemática da produção dos sentidos. Uma das principais observações que eles fizeram diz respeito à crença segundo a qual os programas exibidos pela televisão são repletos de sentidos potenciais. Contudo essa significação torna-se objeto de investida por parte da ideologia dominante na tentativa de propor um sentido preferencial, articulado com os seus interesses. Ainda que posteriormente essa noção seja interrogada, Fiske propõe começar com a semiótica tradicional para entender como a televisão produz sentidos que sirvam aos interesses dominantes da sociedade, e como promove a circulação dos mesmos entre audiências variadas.

A análise do texto televisivo consiste em compreender os códigos usados pelas mensagens e suas relações. Códigos são vínculos entre produtores, textos e audiências e são os agentes da intertextualidade através dos quais os textos se interrelacionam numa rede de sentidos que constituem nosso mundo cultural. Como esses códigos trabalham numa estrutura hierárquica complexa, suas categorias são arbitrárias e escorregadias.

Mas o autor tem um ponto de partida relevante: a realidade já codificada. Ele esclarece que o modo pelo qual nós conhecemos e produzimos sentido do mundo é uma operação realizada através dos códigos de nossa cultura. A realidade nunca é bruta. O que Fiske explica é que quando uma porção desta realidade torna-se uma mensagem televisiva entram em operação os códigos técnicos e as convenções representacionais do meio para apresentá-la de tal modo que a torne (a) tecnologicamente transmissível e (b) um texto cultural apropriado para as audiências.

O autor apresenta esses códigos em três níveis, lembrando que, na prática, eles estão interrelacionados. Os códigos da televisão:

ANIMUS Rev. Interamericana de Comunicação Midiática, Santa Maria, v.10, n.19, sem. 2011, E-ISSN 2175-4977 
$1^{\circ}$ nível: REALIDADE (convenções culturais): aparência, vestuário, maquiagem, ambiente, comportamento, fala, gesto, expressão etc, que são codificados num segundo nível pelos códigos técnicos;

$2^{\circ}$ nível: REPRESENTAÇÃO (códigos técnicos): câmera, iluminação, edição, música, som. Através destes códigos são definidas as representações convencionais de narrativa, conflito, personagem, ação, diálogo, cenário, elenco, etc.

$3^{\circ}$ nível: IDEOLOGIA: Este nível orienta a organização dos códigos técnicos dentro de uma coerência e aceitabilidade social que revelam códigos ideológicos, tais como: individualismo, patriarcado, raça, classe, capitalismo etc.

Os códigos técnicos podem ser identificados e analisados. Já os convencionais e ideológicos e as relações entre eles são muito mais elusivas e difíceis de especificar, embora essa seja a tarefa do crítico. Os códigos ideológicos trabalham para organizar outros códigos dentro da produção de um conjunto de sentidos coerente e consistente que constituem o senso comum. Esse processo interrelaciona os três níveis de forma dinâmica, porque o sentido só pode ser produzido quando a realidade, as representações e a ideologia emergem dentro de uma unidade coerente, aparentemente natural.

O trabalho da análise semiótica é o de desconstruir esta unidade e expor sua naturalidade como um construto altamente ideológico. Tal análise tenta revelar como essas camadas de sentido codificadas são estruturadas dentro dos programas televisivos, mesmo quando se trabalha com um trecho pequeno ${ }^{7}$. Para Fiske é justamente isso que nos permite realizar uma leitura analítica detalhada. Por outro lado, essa escolha nos impede de falar de códigos em larga escala, de maneira generalizada.

Fiske argumentou que os programas televisivos são polissêmicos para alcançar amplas audiências populares. Contudo, sendo o texto televisivo produzido por uma instituição capitalista ele necessariamente apoia esta ideologia fazendo com que qualquer produção de sentido resistente seja feita não de forma 'independente' mas, sim, em relação à ideologia dominante. As relações sociais no capitalismo sempre envolvem uma dimensão política - pois são determinadas mais ou menos diretamente pela distribuição desigual de poder - o que faz

\footnotetext{
${ }^{7}$ Fiske desenvolveu sua análise a partir de um conjunto de quatro cenas do seriado americano chamado Hart to Hart. Através da leitura semiótica do texto ele investigou os lugares do herói, da heroína, do vilão e da vilã e o desempenho de cada um dentro no episódio. $\mathrm{O}$ autor analisou até mesmo as anedotas para apontar, através do seriado em questão, como e qual é o papel destinado à mulher na sociedade.
}

ANIMUS Rev. Interamericana de Comunicação Midiática, Santa Maria, v.10, n.19, sem. 2011, E-ISSN 2175-4977 
com que os sentidos emirjam articulados a outros estabelecendo a base para a negociação ou a resistência ${ }^{8}$.

\section{A POLISSEMIA DO TEXTO TELEVISIVO}

Como mencionamos na seção anterior, Fiske propôs começar sua análise com a semiótica tradicional para interrogá-la em outro momento tendo em vista sua afirmação segundo a qual o texto televisivo é um potencial de sentidos capazes de serem vistos a partir de uma variedade de modos de atenção e por uma variedade de espectadores. Por isso o autor procurou caracterizar o texto televisivo como um estado de tensão entre forças de fechamento, em favor de seus sentidos preferenciais, e forças de abertura, que capacitam os diversos espectadores a negociar uma variedade de sentidos apropriados. Segundo ele é preciso estender a análise para que ela revele alguns dos recursos textuais que abram o texto às leituras polissêmicas, cujo esforço consiste em contrariar as tentativas de fechamento ideológico, tornando o texto acessível e popular às suas várias audiências. Este novo momento da análise inclui explorar os principais recursos textuais que constituem essa abertura tais como: ironia, metáfora, piada, contradição, excesso.

Segundo essa abordagem o texto televisivo é lugar de uma luta por sentidos. A hegemonia do texto nunca é total, pois sempre tem que lutar para se impor sobre a diversidade de sentidos que os leitores irão produzir. Mas esta polissemia não é anárquica: os sentidos são estruturados pela distribuição diferenciada de poder textual do mesmo modo que os grupos sociais estão relacionados de acordo com a distribuição diferenciada de poder social. Os sentidos não são iguais, nem facilmente ativados, mas todos existem em relações de subordinação ou oposição aos sentidos dominantes propostos pelo texto. Muitos autores

\footnotetext{
${ }^{8}$ Para entender tanto a produção do programa quanto a produção de sentido a partir dele, nós precisaríamos entender o funcionamento do discurso. Discurso é uma linguagem ou sistema de representação socialmente desenvolvido cuja produção e circulação de um conjunto coerente de sentidos muitas vezes servem aos interesses do grupo social que os construiu. Sua função é naturalizar aqueles sentidos dentro do senso comum, produzindo padrões para nossas relações sociais sustentando nossa experiência social nessa discursividade social. Os autores trabalham numa perspectiva segundo a qual 'discursos são relações de poder'; são práticas sociais que podem promover ou se opor a ideologia dominante. Uma questão central diz respeito à institucionalização destes discursos, em especial pelas indústrias dos media, na medida em que eles são estruturados por um conjunto de convenções socialmente produzido que são tacitamente aceitas tanto pela indústria quanto pelos consumidores. Não temos a intenção de fazer neste capítulo uma discussão mais aprofundada sobre a questão do discurso conforme adotada por estes autores. Gostaríamos apenas de mencionar este aspecto da análise por considerá-lo relevante. Isto porque sabemos que tal empreitada traria desdobramentos metodológicos que fogem do escopo deste texto.
}

ANIMUS Rev. Interamericana de Comunicação Midiática, Santa Maria, v.10, n.19, sem. 2011, E-ISSN 2175-4977 
(Bakhtin, Barthes, Eco) e teorias vão servir de sustentação às possibilidades de abertura aos múltiplos sentidos do texto televisivo.

Essa luta entre fechamento e abertura pode ser vista tanto numa estrutura mais ampla do texto televisivo quanto no micro nível. Dois modos opostos de organização do texto e, portanto, dos sentidos são relevantes aqui. O primeiro é baseado na lógica de causa e efeito. Esta é uma estratégia de fechamento, pois tenta especificar relações entre incidentes ou elementos numa narrativa de acordo com as leis universais da lógica tratando-as como comuns a qualquer pessoa e, portanto, produtoras do senso comum ${ }^{9}$.

O segundo princípio é aquele baseado nas leis de associação e é mais aberto ao permitir uma variedade mais ampla de relações associativas e de produção de sentidos. Aqueles recursos textuais considerados presentes nas tentativas de abertura do texto criam possibilidades para leituras resistentes: todos eles funcionam pelas leis de associação e, sendo assim, são incapazes de especificar com qualquer autoridade final as relações que o leitor deveria produzir entre seus diferentes elementos ou discursos. Nenhum texto é puramente associativo ou lógico. Todos contêm ambos os princípios e a tensão entre eles é parte da luta textual entre fechamento e abertura, entre dominação e resistência.

Raymond Williams defende que o modo típico de organização dos textos no macro nível é essencialmente associativo e usa o termo fluxo para expressar este princípio. A partir disso a perspectiva adotada para análise do texto televisivo recebe inspiração da proposta deste autor. Como veremos a concepção de Williams, segundo a qual a televisão é um fluxo, é o "lugar clássico dentro da teoria cultural britânica para a discussão de como o texto televisivo pode ser constituído como objeto de estudo" (Brunsdon, 1990, p. 69, tradução nossa). O conceito de fluxo integra a prática textual televisiva com as experiências dos espectadores, e ao mesmo tempo reconhece as bases institucionais da transmissão.

\footnotetext{
${ }^{9} \mathrm{O}$ realismo clássico é um exemplo deste princípio na prática: todas as ações tanto têm uma causa como uma conseqüência, todas as narrativas começam com uma interrupção do status quo que passa a ser trabalhado através de uma resolução que completa a cadeia de incidentes e deixa tanto a narrativa quanto o espectador num estado final de equilíbrio. Não há irrelevâncias sem explicação num texto realista clássico. Todas as coisas são logicamente relacionadas umas com as outras e contribuem para o sentido da narrativa. A construção do realismo numa teia de conexões entre todos os seus elementos repousa em sua auto-apresentação como natural, como o modo senso comum de produzir sentido do mundo numa sociedade racionalista, empiricista e científica tal como a ocidental contemporânea. Cf. Fiske, 1987.
}

ANIMUS Rev. Interamericana de Comunicação Midiática, Santa Maria, v.10, n.19, sem. 2011, E-ISSN 2175-4977 


\section{ASSISTINDO O FLUXO}

O que a análise cultural indica é o fato de que a televisão corresponde a um dos principais domínios na contemporaneidade através dos quais a cultura circula e é produzida. Tal aspecto é evidente nas formulações de Williams, pois ele foi um dos primeiros e principais teóricos a descrever e analisar a televisão levando em consideração sua dimensão tecnológica, mas particularmente sua dimensão cultural. Essa proposta analítica foi desenvolvida em seu livro Television: technology and cultural form (1974). Com ela o autor se esquivou de um determinismo tecnológico e focou nos processos históricos e sociais que concorrem para a construção da televisão enquanto prática cultural.

Para Williams a televisão é um meio cujo discurso deriva tanto de sua tecnologia quanto do conteúdo dos programas. Ele propôs um conceito de televisão ao qual incorporou novas relações estruturais. Anteriormente, as pessoas se dedicavam a atividades distintas tais como um ler um livro, ver uma peça ou uma partida de futebol com uma expectativa e uma atitude únicas. Na televisão, esses eventos separados tornam-se uma sequência unificada, pois a maioria das pessoas alega assistir televisão e não uma lista específica de programas, o que caracteriza tal transmissão como algo maior do que programas unitários. O que ele propôs, então, foi um estudo da televisão como transmissão das unidades de fato, sua duração e a natureza da justaposição de imagens e sons enviados aos telespectadores, além de uma abordagem sobre o que os telespectadores experimentam com a transmissão televisiva. Ao estabelecer essa compreensão, Williams ressaltou que a programação televisiva se constitui, portanto, de forma sequencial e interrompida, o que evidencia um contínuo simbólico que se caracteriza não pela sucessão definida de partes independentes, mas pelo imbricamento de fragmentos oriundos de diferentes formatos televisivos, isto é, pelo fluxo - uma reunião planejada e contínua de unidades de programas que estão sempre acessíveis.

A proposta de Williams incluiu intervenções dentro do processo de transmissão, a saber, as escolhas que os telespectadores fazem quando trocam de canal, bem como considerações sobre o contexto no qual a assistência televisiva ocupa lugar. Com base nisso, estudar a televisão não significa simplesmente dedicar-se àquilo que ela transmite, mas, de forma específica, significa atentar-se para o próprio processo pelo qual os conteúdos se realizam no fluxo televisivo. Isso implica, portanto, observá-los não de forma descontextualizados do momento de sua exibição, mas, compreendê-los no âmbito das

ANIMUS Rev. Interamericana de Comunicação Midiática, Santa Maria, v.10, n.19, sem. 2011, E-ISSN 2175-4977 
dinâmicas e processos que integram os programas no instante mesmo em que eles se realizam para o telespectador; apreendê-los, desse modo, no contexto de seu "ato exibicional".

A abordagem de Williams é importante e indica que o fluxo televisivo precisa ser examinado em termos tanto do texto quanto da recepção para que se entendam os sentidos culturais e sociais em circulação. Como os espectadores participam do fluxo? Eles "seguem o fluxo" de imagens e sons ou intervêm ativamente nesta corrente de programas, intervalos comerciais e anúncios? Qual é o texto que resulta desta intervenção?

\section{A PERSPECTIVA DA AUDIÊNCIA}

Os autores se concentraram em entender a televisão a partir da perspectiva de suas audiências. Por isso procuraram ler as mensagens como textos e atentar para os sentidos e prazeres que são elaborados a partir deles e o modo como são incorporados na rotina diária de suas audiências. Um programa torna-se um texto no momento da sua leitura, ou seja, quando sua interação com suas várias audiências ativam alguns dos sentidos/prazeres que ele é capaz de provocar. E assim ele pode estimular a produção de vários textos de acordo com as condições sociais de recepção e configurar-se como um lugar de lutas pelo sentido que reproduz os conflitos de interesse entre os produtores e consumidores da mercadoria cultural.

Tal perspectiva busca afastar-se das teorias do sujeito inspiradas tanto no estruturalismo quanto no marxismo porque, embora elas tenham dado atenção ao papel do sujeito no processo de produção de sentido, o coloca numa posição unificada que nega quaisquer contradições possíveis. O discurso constrói determinadas posições de sujeitos que seriam plenamente preenchidas e atenderiam às expectativas e demandas da ideologia dominante.

Uma referência a este respeito é a teoria de Louis Althusser (1980) sobre os Aparelhos Ideológicos do Estado (AIE). Para ele ideologia é uma prática social dinâmica, que se reproduz constantemente no funcionamento ordinário dos aparatos. Ela também trabalha no micro nível dos indivíduos. Althusser acredita que nós somos todos constituídos como sujeito na ideologia pelos AIE, que as normas ideológicas naturalizadas em suas práticas constituem não apenas o sentido de mundo para nós, mas também nosso sentido de nós mesmos e de nossas relações com outras pessoas. Assim, cada um de nós é constituído como um sujeito na e para a ideologia. O sujeito, portanto, é uma construção social e não natural. Althusser adota

ANIMUS Rev. Interamericana de Comunicação Midiática, Santa Maria, v.10, n.19, sem. 2011, E-ISSN 2175-4977 
os termos interpelação e chamamento para descrever este processo no discurso. Eles derivam da ideia de que qualquer linguagem é parte das relações sociais e que na comunicação com alguém nós estamos reproduzindo essas relações. O chamamento é o processo pelo qual a linguagem identifica e constrói uma posição social para o sujeito. Interpelação é o processo mais amplo segundo o qual a linguagem constrói as relações sociais para ambas as partes num ato comunicativo e assim localiza-os num mapa mais amplo de relações sociais em geral.

Mesmo atentos aos modos pelos quais a televisão lança mão para interpelar seus espectadores, esses autores argumentaram que a resposta do telespectador à interpelação é parcial. Fiske (1987, p. 17) afirmou que o espectador é "um produtor de textos, um produtor de sentidos e prazeres", o que inclui subverter as representações televisivas dominantes. Enquanto os textos oferecem alguns sentidos "mais vigorosamente do que outros", e servem para limitar o "terreno dentro do qual os sentidos podem ser produzidos", para Fiske o espectador tem supremacia. Isso vai além da noção de que os espectadores encontram subtextos dentro de textos hostis e dominantes para produzir leituras redentoras.

Essa habilidade produtiva é o resultado de experiência social ou treino, seja formal ou informal. Não é um dom inato, mas uma habilidade adquirida. É uma prática social, é ideológica e são os meios pelos quais a experiência sócio-cultural, o texto em questão, e suas relações intertextuais, são colocadas juntas em um momento produtivo de interação (FISKE, 1987, p. 17, tradução nossa).

O sujeito que emerge desta perspectiva é aquele produzido socialmente, que vive numa formação social particular e que é constituído por uma complexa história cultural que é tanto social quanto textual. Sua subjetividade resulta tanto da experiência social real quanto da experiência mediada ou textual e exerce uma influência significativa na construção dos sentidos. A produção de sentido a partir de um texto tem similaridades com o processo da construção da subjetividade dentro da sociedade. O leitor produz sentidos que derivam da intersecção de sua história social com as forças sociais estruturadas dentro do texto. $\mathrm{O}$ momento de leitura é quando o discurso do leitor encontra o discurso do texto. Quando esses discursos sustentam diferentes interesses a leitura torna-se a reconciliação deste conflito. Mas, na análise feita por estes autores as relações sociais têm primazia, pois elas carregam recompensas e sanções imediatas que as tornam muito mais poderosas em sua efetividade do que qualquer programa televisivo. Se por um lado, os espectadores são conscientes da lacuna 
entre as representações da televisão e a realidade, por outro, essa distância não parece existir na experiência das relações sociais. A efetividade das relações sociais na construção da subjetividade é maior do que a da televisão, pois essas relações sociais parecem mais reais.

Os trabalhos desenvolvidos segundo esta perspectiva ajudaram a estabelecer a etnografia como método válido de estudo da audiência. $\mathrm{O}$ objeto do estudo etnográfico é o modo pelo qual as pessoas vivem sua cultura. Seu valor repousa em sua mudança de ênfase distanciando-se da construção textual e ideológica do sujeito para situá-lo histórica e socialmente. Ela nos lembra que pessoas de fato, em situações concretas, assistem e apreciam programas televisivos. Ela reconhece a diferença entre os sujeitos, apesar de sua construção social, e pluraliza os sentidos e prazeres que eles encontram na assistência à televisão. Ela assim contradiz teorias que focam na singularidade dos sentidos da televisão e de seus sujeitos leitores, tornando-nos capaz de dar conta da diversidade tanto dentro da formação social quanto dentro do processo da cultura. Um estudo etnográfico pode tomar a forma observacional a fim de se ver como a televisão é integrada dentro da vida doméstica e familiar, ou pode partir das respostas dadas pelos espectadores ou pode, ainda, combinar ambos. Todos esses caminhos traçaram diferenças entre espectadores, modos de assistir, e os sentidos e prazeres produzidos.

Nesta análise da pluralidade da televisão, evidencia-se sua necessidade em falar com diferentes vozes e sotaques para alcançar os vários grupos em nossa sociedade contemporânea, heterogênea, capitalista e democrática. A televisão de algum modo sustenta a ideologia dominante ao mesmo tempo em que precisa subvertê-la. De outro modo ela não terá apelo junto a uma ampla audiência cuja identidade social raramente é compatível com a ideologia dominante. Disso advém a importância de se reavaliar o papel ativo dos espectadores na produção de sentidos a partir dos textos televisivos. Esses espectadores não interrompem a interpretação quando um programa termina, pois eles discutem o que assistiram uns com os outros.

Outro aspecto que a abordagem etnográfica tornou observável diz respeito ao fato de que a televisão deve também ser capaz de ser assistida em diferentes modos de atenção, o que Hartley (1982) chamou de regimes de assistência. Espectadores assistem televisão como uma atividade básica e, enquanto o fazem, realizam outras atividades como ler jornal, conversar, estudar. 
Essa abordagem da audiência nos conduziu a duas proposições principais: a audiência televisiva é composta de uma ampla variedade de grupos e não por uma massa homogênea; e esses grupos lêem ativamente o texto televisivo para produzir a partir dele sentidos que conectem com sua experiência social.

\section{DIVERSIDADE DE AUDIENCIAS E MODOS DE ENDEREÇAMENTO: DESDOBRAMENTOS E POSSIBILIDADES DA ANÁLISE CULTURAL DA TELEVISÃO}

O modo como os Estudos Culturais investigaram a televisão, colocando a cultura no centro da abordagem, pode ser considerado um dos investimentos mais importantes desse projeto político-teórico, pois é esse elemento analítico que instiga e promove inovações e descobertas nos trabalhos realizados nesta área. Os esforços dos pesquisadores em combinar perspectivas teóricas e abordagens metodológicas ainda rendem muitos frutos na análise dos processos que envolvem a relação dos meios de comunicação com a sociedade e a cultura contemporâneas. Em leituras renovadas a semiótica, o estruturalismo, a etnografia continuam presentes na pesquisa.

Nesta seção final dedicar-nos-emos a uma proposta teórico-metodológica que tem origem nos estudos fílmicos baseados na teoria Screen e que, ao ser pensada para os estudos de televisão - a partir do encontro dos Estudos Culturais e dos estudos de cinema -, passou por uma revisão de tal envergadura que se mostrou fundamental a muitas pesquisas sobre televisão que vêm sendo desenvolvidas contemporaneamente ${ }^{10}$. Estamos nos referindo aos modos de endereçamento.

Os modos de endereçamento são uma importante alternativa de análise em estudos sobre conteúdos audiovisuais. Antes de lidar com esta metodologia na análise de programas televisivos retornaremos ao primeiro emprego dos modos de endereçamento, que data dos anos 1970 e que foi inicialmente pensado para a análise fílmica. Este movimento se faz preciso para que entendamos o novo olhar que tal metodologia adquiriu a partir das

\footnotetext{
${ }^{10}$ No Brasil, há investimentos nessa perspectiva no âmbito do Grupo de Pesquisa em Análise de Telejornais, coordenado pela professora Itânia Gomes do PPGCOM/UFBA. Mais especificamente, as pesquisas desenvolvidas nesse grupo têm investido numa abordagem dos modos de endereçamento de programas particulares de telejornalismo brasileiro. Também o Grupo de Pesquisa em Comunicação, Mídia e Cultura, coordenado pela professora Simone Rocha do PPGCOM/UFMG, têm procurado adotar essa perspectiva teóricometodológica na análise de produtos ficcionais televisivos. Estes grupos trabalham a partir de uma articulação dessa teoria à noção de gênero como categoria cultural.
}

ANIMUS Rev. Interamericana de Comunicação Midiática, Santa Maria, v.10, n.19, sem. 2011, E-ISSN 2175-4977 
atualizações advindas do questionamento de sua formulação inicial. É justamente esta mudança no olhar que torna os modos de endereçamento uma metodologia nos estudos sobre televisão.

Segundo Elizabeth Ellsworth (2001), a noção de modos de endereçamento surge com a preocupação de compreender as relações estabelecidas entre o texto de um filme e a experiência de seus espectadores, podendo ser expressa pela seguinte pergunta: quem este filme pensa que você é? Nesse contexto, a primeira formulação dos modos de endereçamento seria um conjunto de mecanismos imateriais cristalizados na narrativa de modo a tentar propor uma ligação sólida entre o filme e a audiência real. O sucesso de bilheteria seria advindo do refinamento de se equiparar a audiência suposta a real.

Contudo, o desenvolvimento de pesquisas empíricas revelou que, na prática, o filme erraria o seu alvo, pois o entrelaçamento de categorias sociais nas quais a experiência humana se efetiva é muito mais complexo do que aquelas levadas em conta na produção de um filme, de modo que isso não se mostrou capaz de assegurar uma resposta por parte dos espectadores condizente com aquela esperada pela instância produtora. Além disso, espectadores que estavam a princípio fora do público imaginado pelo filme poderiam se identificar com os anseios expressos pela trama. Diante desse novo quadro, novas explicações foram propostas tendo como pano de fundo a problemática dos modos de endereçamento. A primeira dizia da revisão dos modos de endereçamento enquanto uma forma de interpelação do filme que visava convocar seus espectadores a vê-lo de um determinado lugar preferencial. A segunda explicação foi a constatação de que um filme não trabalharia somente com um, mas que em seu interior trabalhariam endereçamentos múltiplos.

Outro aspecto dos modos de endereçamento pode ser expresso pela pergunta: quem este filme quer que você seja? Esta nova etapa tem como pressuposto uma preocupação em vincular o potencial de difusão simbólica do cinema a processos de mudança social e ao aumento da capacidade crítica de leitura por parte dos espectadores. Sendo assim, seus principais teóricos procuravam mostrar que o modo como os filmes endereçavam suas mensagens a seu público acabava por privilegiar uma determinada posição de sujeito em detrimento de outras possibilidades da experiência humana e que quando davam a ver tais outras possibilidades o faziam de maneira estereotipada, negativa, como quem diz não façam isso, pois é errado. Os filmes eram vistos como importantes aparelhos ideológicos que procuravam contribuir para a manutenção de relações desiguais de acesso e poder dentro da

ANIMUS Rev. Interamericana de Comunicação Midiática, Santa Maria, v.10, n.19, sem. 2011, E-ISSN 2175-4977 
sociedade, pois condenavam possibilidades da experiência humana que não estivessem dentro do que o status quo estabelecia. Estes teóricos acreditavam que modelos alternativos de endereçamento presentes nos filmes seriam capazes de despertar nos espectadores uma maior crítica a respeito de sua própria realidade social. Neste contexto, alguns cineastas acabaram por propor novas formas de endereçamento que privilegiassem um aspecto mais crítico, reflexivo, de seus espectadores. Eis que é do embate entre novas formas de endereçamento e as antigas que surge uma constatação que ajuda a repensar a questão: da mesma maneira que uma teórica feminista pode desejar assistir a filmes que trabalhem a posição de sujeito das mulheres de maneira mais adequada, ela também pode ter vontade de assistir a filmes com um tipo de endereçamento mais tradicional, buscando suprir em si mesma outras necessidades sem que este deslocamento resulte contraditório ou equivocado, pois o prazer e a fantasia dos quais os filmes se valem para estabelecer contato com seu público podem até ser políticos, mas não são apenas. É a partir deste reconhecimento da pluralidade da vida social e da expressão individual que começam a ser desenvolvidas pesquisas de recepção. Com tais pesquisas, as teorizações a respeito dos modos de endereçamento dão um passo rumo à reconfiguração de seu olhar ao chamar a atenção para a centralidade dos receptores no processo de construção dos sentidos dos filmes:

\footnotetext{
Não importa quanto o modo de endereçamento do filme tente construir uma posição fixa e coerente no interior do conhecimento, do gênero, da raça, da sexualidade a partir da qual o filme 'deve' ser lido: os espectadores reais sempre leram os filmes em direção contrária a seus modos de endereçamento, 'respondendo' aos filmes a partir de lugares que são diferentes daqueles a partir dos quais o filme fala aos receptores (ELLSWORTH, 2001, p. 31).
}

Isso porque uma ênfase demasiadamente semiótica, centrada na mensagem, é incapaz de remeter ao lugar no qual os sentidos são compartilhados no cotidiano: a cultura. Esta virada proporcionada pelos estudos de recepção possibilitou também a ruptura com a dicotomia expressa ou por uma relação contestatória/crítica ou por uma relação puramente cúmplice/reacionária com o conteúdo dos filmes. Isso acontece porque estes estudos apontaram para uma maior complexidade feita nos usos dos conteúdos das obras.

É dentro deste novo panorama os modos de endereçamento têm seu vigor explicativo renovado e passam a ser percebidos como um evento que transita entre o social e o individual: 
"o evento do endereçamento ocorre num espaço que é social, psíquico, ou ambos, entre o texto do filme e os usos que o espectador faz dele" (ELLSWORTH, 2001, p. 13). Diante disto, Ellsworth caracterizou os modos de endereçamento como uma escolha elaborada pela instância produtiva em detrimento de outras possíveis para a realização de um filme - o que pode ser estendido para produtos midiáticos em geral. $\mathrm{O}$ que se quer explicitar com esta formulação é que a referida escolha é construída com base no estabelecimento de um determinado tipo de relação com o público, relação esta de caráter histórico, que envolve também expectativa e desejo.

Segundo Daniel Chandler, modos de endereçamento são as maneiras como as relações entre endereçador e endereçado são construídas em um texto. "Para se comunicar, o produtor de um texto precisa fazer algumas suposições a respeito de uma audiência pretendida: reflexos dessas suposições podem ser encontrados no texto" (Chandler, 2009, tradução nossa). Assim, pensar quem é a audiência não só a define, mas também o próprio produto, já que isto interfere nas escolhas de seu processo de construção.

\section{MODOS DE ENDEREÇAMENTO E A PESQUISA EM TELEVISÃO}

Agora podemos considerar algumas das particularidades dos modos de endereçamento na aplicação a produtos televisivos nos quais eles estão relacionados,

aquilo que é característico das formas e práticas comunicativas específicas de um programa, diz respeito ao modo como um programa específico tenta estabelecer uma forma particular de relação com sua audiência [...] a partir da construção de um estilo, que o identifica e que o diferencia dos demais. (GOMES, 2007, p. 20).

As reflexões de Fiske e Hartley (1978) se mostraram fundamentais nesse novo terreno de pesquisas. A abordagem de Hartley (1982) mostra as estratégias conceituais pelas quais as instituições televisivas constroem para si uma imagem da audiência unificada. Mas a conveniência desta estratégia para as instituições não significa que as audiências tenham que compartilhá-la e, de fato, elas não o fazem. Para Hartley a televisão lida com necessidades que competem entre si: a de apelar a uma ampla diversidade de audiências e a de disciplinálas e controlá-las ao ponto no qual elas possam ser atingidas por uma mercadoria cultural produzida industrialmente. Para alcançar isto, a televisão tem que reconhecer que uma diversidade de audiências requer uma diversidade de modos de endereçamento:

ANIMUS Rev. Interamericana de Comunicação Midiática, Santa Maria, v.10, n.19, sem. 2011, E-ISSN 2175-4977 
Longe de buscar fixar apenas uma posição de sujeito, a televisão tem desenvolvido uma diversidade de modos de endereçamento, de pontos de vista, de gêneros de programas, de estilos de apresentação. Ela é caracterizada, em resumo, pelo excesso, tanto de posições que podem ser facilmente reconhecidas quanto de prazeres que podem ser disciplinados dentro do que já é familiar, de formas previsíveis (HARTLEY, 1982, p. 16).

Quanto à questão do estilo, Hartley chama atenção para esse aspecto segundo o qual os modos de endereçamento dizem respeito ao tom de um determinado programa, aquilo que o individualiza em meio aos demais. Jornais e programas em geral devem incluir uma orientação para seus endereçados como parte da mensagem. Contudo, exceto de modo mais geral e abstrato, os produtores não conhecem quem são os endereçados. Eles devem desenvolver um modo de endereçamento prático que expressa não apenas o conteúdo dos eventos que eles relatam, mas também sua orientação em direção ao espectador ou leitor, uma vez que essa orientação é um elemento constituinte inevitável de toda linguagem. Ela é o tom de um jornal ou de um programa, aquilo que o distingue dos demais que com ele competem e que nos dirige muito de seu apelo enquanto espectadores e leitores.

É com base em Hartley que Gomes (2007, p. 22) afirma que "nessa perspectiva, portanto, o conceito nos leva não apenas à imagem da audiência, mas ao estilo, às especificidades de um determinado programa”. Sua utilidade, a partir de sua atualização, está no fato de que ela permite-nos investigar aquilo que é característico da realidade material do produto, as especificidades do meio bem como lidar com os contextos culturais aos quais um produto está relacionado.

Gomes (2007) apresenta uma revisão sobre o assunto ressaltando o aspecto relacional entre uma proposta elaborada pela instância produtiva e sua audiência imaginada. Esta suposição dá base para que os programas criem uma determinada identidade que mobiliza linguagem própria, assim como estruturas narrativas e argumentativas específicas para dialogar com aquele público em questão.

Essa mudança de foco que leva em consideração as audiências se constitui a partir da compreensão de que as escolhas operadas pela produção não são impostas aos sujeitos, mas precisam estabelecer um ponto de encontro com os espectadores, como forma de criar uma relação específica de comunicação. E esse ponto de encontro se constitui na cultura, nos modos como as estratégias empreendidas nas instâncias produtoras se baseiam num conjunto de sentidos e entendimentos que sejam amplamente compartilhados num dado contexto histórico-cultural. Dessa forma, modo de endereçamento passa a remeter a algo que é próprio 
de um dado texto comunicativo e do tipo de relacionamento que ele quer construir com seu público-alvo sim, mas que se institui e fundamenta pela mediação da cultura.

Uma das grandes contribuições que esses autores ofereceram aos estudos de televisão baseia-se nessa leitura dos modos de endereçamento enquanto formas particulares de produção e circulação da cultura dentro de processos comunicativos específicos que nos permitam identificar e avaliar tanto os entrelaçamentos que produzem entre si, e que nos permitiriam apreender não só os diálogos constituídos em cada uma dessas esferas do televisual, quanto os processos de significação do fluxo televisivo.

\section{REFERÊNCIAS}

ALTHUSSER, L. Ideologia e aparelhos ideológicos do Estado. 3. ed. Lisboa: Presença, 1980.

ANG, I. Watching 'Dallas': Soap Opera and the melodramatic imagination. London: Methuen, 1985.

BRUNSDON, C. Television: aesthetics and audiences. In: MELLENCAMP, P. (Ed). Indianápolis: Indiana University Press, 1990.

CHANDLER, D. Modes of address. In: Semiotics for beginners. Disponível em: <http://www.aber.ac.uk/media/Documents/S4B/semiotic.html>. Acesso em: 10 dez. 2009.

ELLSWORTH, E. Modos de endereçamento: uma coisa de cinema; uma coisa de educação também. In: SILVA, T. T. (Org.). Nunca fomos humanos. Belo Horizonte: Autêntica, 2001.

ESCOSTEGUY, A. C. D. Cartografias dos estudos culturais. Belo Horizonte: Autêntica, 2001.

FISKE, J. Television culture. London: Routledge, 1987.

FISKE, J.; HARTLEY, J. Reading television. London: Methuen, 1978.

GOMES, I. M. M. Questões de método na análise do telejornalismo: premissas, conceitos, operadores de análise. Revista da Associação Nacional de Programas dePós-Graduação em Comunicação - E-compós, Brasília, v. 8, [n. 1], 2007.Disponível em: < http://www.compos.org.br/seer/index.php/e-compos/article/view/126/126>. Acesso em: 20 abr. 2011

ANIMUS Rev. Interamericana de Comunicação Midiática, Santa Maria, v.10, n.19, sem. 2011, E-ISSN 2175-4977 
HALL, S. Codificação/decodificação. In:

Da Diáspora: identidades e mediações culturais. Belo Horizonte: Editora da UFMG, 2003a.

HALL, S. Reflexões sobre o modelo codificação/decodificação: uma entrevista com Stuart Hall. In: . Da Diáspora: identidades e mediações culturais. Belo Horizonte: Editora da UFMG, 2003b.

HALL, S. Estudos culturais: dois paradigmas. In: Da Diáspora: identidades e mediações culturais. Belo Horizonte: Editora da UFMG, 2003c.

HARTLEY, J. Understanding News. London; New York: Routledge, 1982.

MORLEY, D. The 'Nationwide' audience. London: British Film Institute, 1980.

MULVEY, L. Visual pleasure and narrative cinema. Screen, v. 16, n. 3, 1974, p.6-18.

POSTMAN, N. Amusing ourselves to death. New York: Viking Penguin Inc., 1985.

WILLIAMS, R. Television: technology and cultural form. London: Routledge, 1974.

WILLIAMS, R. The politics of modernism: against the new conformists. London: Verso, 1989.

Resumo sobre o autor:

Simone Maria Rocha é Doutora em Comunicação e Cultura pela UFRJ, com pós-doutorado em Comunicação pela UFMG. É professora do PPGCOM/UFMG e coordenadora do Grupo de Pesquisa em Comunicação, mídia e cultura.

ANIMUS Rev. Interamericana de Comunicação Midiática, Santa Maria, v.10, n.19, sem. 2011, E-ISSN 2175-4977 